\title{
Comparison of Coblation Tonsillectomy vs Dissection Tonsillectomy
}

\author{
Vivek Sasindran, Nidhi Mathew, A. K. Shabna, B. Harikrishan \\ Pushpagiri Institute of Medical Science and Research Centre, Thiruvalla, India \\ Email: viveksasindran@hotmail.com
}

How to cite this paper: Sasindran, V., Mathew, N., Shabna, A.K. and Harikrishan, B. (2019) Comparison of Coblation Tonsillectomy vs Dissection Tonsillectomy. International Journal of Otolaryngology and Head \& Neck Surgery, 8, 49-60. https://doi.org/10.4236/ijohns.2019.81006

Received: August 10, 2018

Accepted: January 4, 2019

Published: January 7, 2019

Copyright $\odot 2019$ by author(s) and Scientific Research Publishing Inc. This work is licensed under the Creative Commons Attribution International License (CC BY 4.0).

http://creativecommons.org/licenses/by/4.0/ (c) (i) Open Access

\begin{abstract}
Background: Tonsillectomy is one of the most commonly performed surgical operations in the recent years. It is mainly done for chronic tonsillitis and obstructive symptoms. Aims \& Objectives: To compare the operating time, intraoperative blood loss, postoperative pain, time needed to return to normal diet and activity in coblation and dissection tonsillectomy. Methods: This is a prospective study done at Pushpagiri Medical College for a period of one and a half years from March 2015 to September 2016. Out of the 50 patients, 25 underwent coblation tonsillectomy and 25 underwent conventional dissection tonsillectomy. Method of surgery depended on patients' or parents' choice. Intra operative measures like operating time, blood loss and post-operative morbidity were measured and compared. Results: In this study, there was significant difference in intraoperative time in coblation tonsillectomy compared to cold dissection tonsillectomy (mean operative time-13.4 minutes for coblation and 20.4 minutes for cold dissection with $\mathrm{p}$ value less than 0.05$)$. Intraoperative blood loss was significantly less for coblation $(18.9 \mathrm{ml})$ compared to traditional $(43.0 \mathrm{ml})$ with $\mathrm{p}$ value 0.002 . Average postoperative pain score 6 hours after operation was 7.6 for coblation and 8.5 for cold dissection with a significant $\mathrm{p}$ value of 0.002 . Average time taken to return to normal diet among coblation was 6.4 days and dissection was 7.0 days with $\mathrm{p}$ value of 0.078 which is not statistically significant. However, average time taken to return to normal activity among coblation was 6.3 days and dissection was 7.1 days with a significant $p$ value of 0.024 . Conclusion: Coblation tonsillectomy significantly reduces the operation time, intraoperative blood loss, immediate postoperative pain, and patient returns early to regular routine, but with a higher cost.
\end{abstract}

\section{Keywords}

Tonsillectomy, Cold Dissection, Coblation, Operation Time, Postoperative Pain 


\section{Introduction}

Palatine tonsils are collection of lymphoid tissue situated in oropharynx within tonsillar fossa. Tonsils are important in children because of its role in immunology and defense mechanism. Antibody secretion, especially secretory IgA production, plays an important role in mucosal defense mechanism. For unknown etiology, their protective mechanism sometime fails and becomes seat of infection causing sore throat, fever and other complications. This requires removal of the diseased tonsils.

Tonsillectomy is one of the most commonly performed surgical operations in the recent years. It is mainly done for chronic tonsillitis and obstructive sleep apnea (OSA). Standard or extracapsular tonsillectomy, which is typically performed under general anesthesia involves surgically removing the palatine tonsil and capsule, and then sealing blood vessels (hemostasis) with ligatures (ties), sutures, or heat (diathermy) [1]. There are various methods described in literature for tonsillectomy which includes dissection, guillotine, cryosurgery, monopolar and bipolar diathermy dissection, thermal welding, ultrasonic removal, radiofrequency surgery and laser surgery [2]-[10]. But the superiority of one over another has not been clearly demonstrated. For recurrent acute tonsillitis, it has been reported that watchful waiting results in a higher cost compared to tonsillectomy.

As regard to the different surgical techniques, improving the intra-operative efficiency and reducing post-operative morbidity are the most important parameters in assessing the best method in this procedure. The most common side effects of tonsillectomy are pain and post-operative bleeding, but patients may also experience difficulty in swallowing, nausea, vomiting, throat and ear pain, weight loss, dehydration, fever and airway obstruction.

On comparing coblation tonsillectomy and cold dissection tonsillectomy, many studies have been done with the above-mentioned parameters. Cold dissection tonsillectomy is done with cold steel instruments and hemostasis is obtained with either ligation technique or by using electrocautery. Coblation tonsillectomy means tonsillectomy done with coblation assisted procedure using Arthro Care Evac 70 Arthro Wand [11] (Arthro Care Corp., Sunnyvale, CA) handpiece. It can be used for subcapsular, intracapsular or extracapsular dissection. Coblation process involves passing a bipolar radiofrequency current through isotonic saline to convert it into an ionized plasma layer. This layer effectively disrupts intercellular molecular bonds in the tissues resulting in a vaporization effect. Surface irrigation and suction are applied to prevent significant pooling of saline inside the oral cavity. Coblation generates a substantially lower thermal effect compared to electrocautery, estimated between $45^{\circ} \mathrm{C}-85^{\circ} \mathrm{C}$, with a subsequent presumption of diminished collateral thermal damage to surrounding tissues [11].

The temperature reaches up to $40^{\circ} \mathrm{C}-70^{\circ} \mathrm{C}$ in Coblation while in electrocautery, which is used in conventional cold dissection tonsillectomy it reaches up to 
$400^{\circ} \mathrm{C}-600^{\circ} \mathrm{C}$. The thermal penetration is minimal with Coblation, but it is usually very deep with electrocautery. The target tissue undergoes dissolution in Coblation, but there is rapid heating, charring, burning \& cutting of target tissue with electrocautery. Finally, surrounding tissues are not much affected with Coblation. They undergo minimal dissolution. But with electrocautery there is inadvertent charring/burning of surrounding tissue [12].

\section{Objectives}

To compare the operating time, intra operative blood loss, postoperative pain, time needed to return to normal diet and activity in coblation and dissection tonsillectomy.

\section{Materials and Methods}

\subsection{Type of Study and Source of Data}

A prospective study was conducted for a period of one and a half years from March 2015 to September 2016 to compare the operation time, intraoperative blood loss, postoperative pain, time needed to regain the normal diet and activity in coblation and dissection type of tonsillectomy from the patients undergoing tonsillectomy in ENT department of Pushpagiri Institute of Medical Sciences \& Research Centre, Thiruvalla, Kerala.

\subsection{Inclusion Criteria}

1) Chronic tonsillitis-7 or more episodes/year or 5 or more episodes/year for 2 years or 3 or more episodes/year for 3 years.

2) Obstructive symptoms related to tonsil hypertrophy.

3) Patients of both sex between the age group 5 to 45 years come under the study.

\subsection{Exclusion Criteria}

1) Age less than 5 year and more than 45 year.

2) Patients with a history of a bleeding disorder.

3) History of tonsillitis within three weeks prior to surgery.

\subsection{Method of Data Collection}

The patients were selected consecutively as and when they were presented during the study period of one and a half years from March 2015 to September 2016 in ENT department of Pushpagiri Institute of Medical Sciences and Research Centre, Thiruvalla, Kerala, considering the inclusion and exclusion criteria. This study involved 50 patients out of whom 25 underwent coblation tonsillectomy and the rest 25 underwent conventional cold steel tonsillectomy. The patients were free to choose the procedure. A complete history, ENT examination and appropriate investigations were done to arrive at the correct diagnosis.

During admission day, all patients and parents were taught how to fill the 
post-operative pain score form. Pre-operatively, single dose of Amoxicillin-Clavulanic acid injection was given for all the patients. Operations were done using a standard technique of either cold dissection tonsillectomy or coblation tonsillectomy. Surgery was done under general anesthesia. The patient was put in Rose position and adequate exposure of Oropharynx was obtained by Boyle Davis mouth gag.

Surgical time was measured from the insertion of Boyle-Davis mouth gag to the final hemostasis and removal of mouth gag. Time taken was recorded inminutes. Intraoperative blood loss was measured by weighing the tonsil swab before and after tonsillectomy and by measuring the amount in the suction bottle in dissection tonsillectomy. For coblation tonsillectomy, blood loss was calculated by deducting the total amount of blood in suction jar with estimated saline used for the surgery.

Postoperative outcomes were obtained via answers to a survey administered to the patient or caregiver. This included a combination of the Wong-Baker FACES pain scale and a set of questions-adapted from questionnaires as detailed by Chang and Myatt (Table 1) - in order to evaluate patients, return to normal diet and activity, pain level. In addition, caregivers were also asked how their daily activity was being affected by their child's recovery course. The care-givers or patient had to fill identical copies of this survey on POD 0, 1, 3, 5 and 7 [13].

Table 1. Patient evaluation questionnaire.

\begin{tabular}{|c|c|c|c|c|}
\hline \multicolumn{5}{|l|}{ Questionnaire: } \\
\hline 1) Have you or your child been drinking? & A. Not at all & $\begin{array}{l}\text { B. Sips reluctantly } \\
\text { when encouraged }\end{array}$ & C. Sips on their own & D. Drinking as usual \\
\hline 2) Have you or your child been eating? & A. Not at all & B. A few mouthfuls & $\begin{array}{l}\text { C. Eating less than } \\
\text { normal }\end{array}$ & D. Eating normally \\
\hline $\begin{array}{l}\text { 3) What kind of foods have you or } \\
\text { your child been eating? }\end{array}$ & $\begin{array}{l}\text { A. Has not been } \\
\text { eating }\end{array}$ & B. Juices and fluids & C. Soft foods & D. Regular diet \\
\hline 4) Have you or your child been talking? & A. Not at all & $\begin{array}{l}\text { B. A few words } \\
\text { quietly }\end{array}$ & $\begin{array}{l}\text { C. In a normal voice but } \\
\text { less talkative than usual }\end{array}$ & D. Talking as usual \\
\hline 5) Have you or your child been active? & $\begin{array}{l}\text { A. No, lying in } \\
\text { bed }\end{array}$ & $\begin{array}{l}\text { B. Reluctant to } \\
\text { sit up in bed }\end{array}$ & C. Sitting up in bed & D. Getting out of bed \\
\hline 6) Has your child been playing? & A. Not at all & B. Playing in bed & $\begin{array}{l}\text { C. Getting up to } \\
\text { watch others }\end{array}$ & D. Getting up to play \\
\hline 7) How have you or your child/s mood been? & A. Silent & $\begin{array}{l}\text { B. Unhappy and } \\
\text { miserable }\end{array}$ & C. A little upset & D. Content, cheerful \\
\hline $\begin{array}{l}\text { 8) Did your child have to miss } \\
\text { school/daycare today? }\end{array}$ & A. Yes & B. No & $\begin{array}{l}\text { C. Does not attend } \\
\text { school/daycare }\end{array}$ & \\
\hline 9) Did you have to miss work today? & A. Yes & B. No & $\begin{array}{l}\text { C. Would not have } \\
\text { worked anyway }\end{array}$ & \\
\hline $\begin{array}{l}\text { 10) Were you able to complete all of your } \\
\text { planned activities and errands for today? }\end{array}$ & A. Yes & B. Some of them & C. No & \\
\hline
\end{tabular}




\subsection{Postoperative Care}

Postoperatively all patients treated with antibiotic (Amoxicillin Clavulanicacid) with doses based on body weight, pain medication (paracetamol), with doses based on body weight and povidone iodine gargle and all of them were discharged at post op day 1. Patients were given verbal as well as written instructions regarding medication at home and guidance regarding food intake and general care. All patients were followed up for 7 days after surgery. Patients were all seen in the outpatient department on the $7^{\text {th }}$ postoperative day and examination of their throat was carried out with a subjective measure about the area of the tonsillar fossa that was healed or covered in slough and the questionnaire form were collected.

\subsection{Statistical Analysis}

The results were compared by paired t-test and Chi-square test and the p-value was calculated. All p-values below 0.05 were considered statistically significant.

\section{Result}

All 50 patients were available for regular post-operative follow-up. A total of 50 cases underwent tonsillectomy out of whom 25 underwent coblation tonsillectomy while the rest underwent conventional cold steel tonsillectomy from March 2015 to September 2016 in ENT department of Pushpagiri Institute of Medical Sciences and Research Centre. All the patients were available for regular post-operative follow up.

The data were analyzed.

\subsection{Operation Time}

Table 2 and Table 3 show intraoperative time for both of the procedures. In our study, the intraoperative time for coblation tonsillectomy ranged from 4 to 30 minutes with an average of $13.4( \pm 7.0)$ minutes while it took about 5 to $40 \mathrm{mi}$ nutes to complete cold dissection tonsillectomy with an average of $20.4( \pm 9.7)$ minutes. Paired T test showed a significant $\mathrm{p}$ value of 0.005 .

\subsection{Intraoperative Blood Loss}

Table 4 and Table 5 show intraoperative estimated blood loss for the procedures. The average blood loss in coblation tonsillectomy ranged from 4 to $66 \mathrm{ml}$

Table 2. Descriptive statistics for operation time based on method.

\begin{tabular}{ccc}
\hline Descriptive statistics & Coblation & Dissection \\
\hline Mean & 13.4 & 20.4 \\
SD & 7.0 & 9.7 \\
Median & 12.0 & 20.0 \\
Minimum & 4.0 & 5.0 \\
Maximum & 30.0 & 40.0 \\
\hline
\end{tabular}


Table 3. Comparison of operation time based on method.

\begin{tabular}{cccccc}
\hline Method & Mean & SD & N & t & p \\
\hline Coblation & 13.4 & 7.0 & 25 & $2.93^{* *}$ & 0.005 \\
Dissection & 20.4 & 9.7 & 25 & & \\
\hline
\end{tabular}

Paired $t$ test significant when $p$ value less than 0.05 .

Table 4. Descriptive statistics for blood loss based on method.

\begin{tabular}{ccc}
\hline Descriptive statistics & Coblation & Dissection \\
\hline Mean & 18.9 & 43.0 \\
SD & 15.0 & 33.1 \\
Median & 15.0 & 30.0 \\
Minimum & 4.0 & 8.0 \\
Maximum & 66.0 & 140.0 \\
\hline
\end{tabular}

Table 5. Comparison of blood loss based on method.

\begin{tabular}{cccccc}
\hline Method & Mean & SD & N & t & p \\
\hline Coblation & 18.9 & 15.0 & 25 & $3.32^{\star *}$ & 0.002 \\
Dissection & 43.0 & 33.1 & 25 & & \\
\hline
\end{tabular}

Paired t test significant when $\mathrm{p}$ value less than 0.05 .

with an average of $18.9( \pm 15.0) \mathrm{ml}$ while it was 8 to $140 \mathrm{ml}$ with an average of $43.0( \pm 33.1) \mathrm{ml}$ in cold dissection tonsillectomy. Again, paired T test showed a significant $\mathrm{p}$ value of 0.002 .

\subsection{Post-Operative Pain}

Table 6 compares post-operative pain scores among coblation tonsillectomy versus dissection tonsillectomy. Average pain score 6 hours after operation was 7.6 for coblation and 8.5 for cold dissection with a significant $p$ value of 0.002 . In postoperative day 5, pain score average was 2.8 for coblation and 3.9 for cold dissection with a significant $p$ value of 0.003 . Thus, there was significantly less pain in coblation six hours and 5 days after the operation. However, there were no differences of pain severity between the two methods at day 1,3 and 7 postoperative.

\subsection{Time to Return to Normal Diet}

Table 7 compares time to return to normal diet among coblation tonsillectomy versus dissection tonsillectomy. Average time taken to return to normal diet among coblation was 6.4 days and dissection was 7.0 days with p value of 0.078 which is not statistically significant.

\subsection{Time to Return to Normal Activity}

Graph 1 compares time to return to normal activity among coblation tonsillectomy versus dissection tonsillectomy. Average time taken to return to normal 


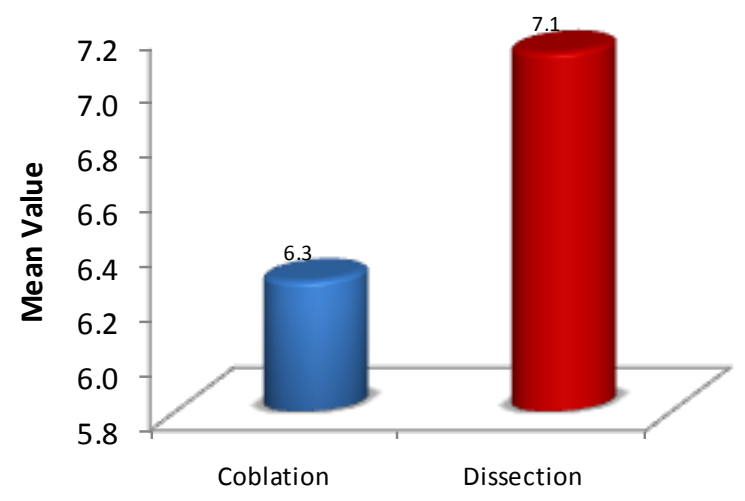

Graph 1. Comparison of time to return to normal activity based on group.

Table 6. Comparison of post-operative pain based on method.

\begin{tabular}{ccccccccc}
\hline \multirow{2}{*}{ Pain } & \multicolumn{3}{c}{ Coblation } & \multicolumn{3}{c}{ Dissection } & \multirow{2}{*}{$\mathrm{t}$} \\
\cline { 2 - 6 } & Mean & SD & Median & Mean & SD & Median & & \\
\hline 6 hours & 7.6 & 0.8 & 8 & 8.5 & 1.0 & 8 & $3.32^{\star *}$ & 0.002 \\
Day 1 & 7.5 & 1.0 & 8 & 7.9 & 1.2 & 8 & 1.24 & 0.220 \\
Day 3 & 5.3 & 1.0 & 6 & 5.9 & 1.4 & 6 & 1.92 & 0.061 \\
Day 5 & 2.8 & 1.2 & 2 & 3.9 & 1.4 & 4 & $3.15^{\star *}$ & 0.003 \\
Day 7 & 0.7 & 1.1 & 0 & 1.2 & 1.5 & 0 & 1.26 & 0.214 \\
\hline
\end{tabular}

Paired $t$ test significant when $\mathrm{p}$ value less than 0.05 .

Table 7. Comparison of time to return to normal diet based on group.

\begin{tabular}{cccccc}
\hline Method & Mean & SD & N & $\mathrm{t}$ & $\mathrm{p}$ \\
\hline Coblation & 6.4 & 1.0 & 25 & 1.8 & 0.078 \\
Dissection & 7.0 & 1.4 & 25 & & \\
\hline
\end{tabular}

Paired t test significant when $\mathrm{p}$ value less than 0.05 .

activity among coblation was 6.3 days and dissection was 7.1 days with a significant $\mathrm{p}$ value of 0.024 .

\subsection{Summary of Results}

Table 8 shows the summary of results of coblation tonsillectomy, whereas Table 9 shows the results of dissection tonsillectomy.

\section{Discussion}

Tonsillectomy is one of the most common operations performed in ENT worldwide. Several investigators have explored alternative methods with novel surgical instrumentation and techniques to maintain intraoperative surgical advantages without sacrificing the patients' postoperative recovery. Tonsillectomy with cold steel forceps (as traditional) consumes longer time than coblation tonsillectomy [14]. 
Table 8. Coblation tonsillectomy.

\begin{tabular}{|c|c|c|c|c|c|c|c|c|c|c|c|c|}
\hline S. No & Age & Sex & $\begin{array}{l}\text { Hospital } \\
\text { number }\end{array}$ & $\begin{array}{l}\text { Blood } \\
\text { loss } \\
\text { (in ml) }\end{array}$ & $\begin{array}{l}\text { Operation } \\
\text { time } \\
\text { (in min) }\end{array}$ & $\begin{array}{c}\text { Normal } \\
\text { diet } \\
\text { (in days) }\end{array}$ & $\begin{array}{l}\text { Normal } \\
\text { activity } \\
\text { (in days) }\end{array}$ & $\begin{array}{l}\text { Pain } 6 \\
\text { hour }\end{array}$ & $\begin{array}{l}\text { Pain } \\
\text { pod } 1\end{array}$ & $\begin{array}{l}\text { Pain } \\
\text { pod } 3\end{array}$ & $\begin{array}{l}\text { Pain } \\
\text { pod } 5\end{array}$ & $\begin{array}{l}\text { Pain } \\
\text { pod } 7\end{array}$ \\
\hline 1 & 27 & M & 482,575 & 20 & 20 & 6 & 6 & 6 & 8 & 6 & 2 & 0 \\
\hline 2 & 45 & F & 470,912 & 43 & 18 & 10 & 10 & 8 & 8 & 6 & 4 & 0 \\
\hline 3 & 6 & M & 485,732 & 8 & 12 & 6 & 6 & 8 & 8 & 6 & 6 & 4 \\
\hline 4 & 7 & $\mathrm{~F}$ & 285,691 & 22 & 24 & 6 & 6 & 8 & 8 & 6 & 2 & 0 \\
\hline 5 & 34 & $\mathrm{~F}$ & 493,695 & 28 & 20 & 7 & 7 & 8 & 8 & 6 & 4 & 0 \\
\hline 6 & 5 & M & 485,968 & 20 & 12 & 6 & 6 & 8 & 6 & 6 & 4 & 2 \\
\hline 7 & 6 & M & 500,698 & 13 & 8 & 6 & 5 & 8 & 6 & 4 & 2 & 0 \\
\hline 8 & 35 & $\mathrm{~F}$ & 527,632 & 48 & 30 & 7 & 7 & 8 & 10 & 6 & 4 & 2 \\
\hline 9 & 45 & $\mathrm{~F}$ & 381,190 & 30 & 20 & 7 & 7 & 8 & 8 & 6 & 4 & 2 \\
\hline 10 & 31 & F & 281,584 & 20 & 20 & 6 & 6 & 8 & 8 & 6 & 4 & 2 \\
\hline 11 & 11 & M & 445,643 & 15 & 13 & 5 & 5 & 8 & 6 & 6 & 2 & 0 \\
\hline 12 & 21 & $\mathrm{~F}$ & 518,984 & 12 & 10 & 6 & 6 & 6 & 8 & 4 & 2 & 0 \\
\hline 13 & 13 & M & 200,574 & 4 & 5 & 5 & 5 & 6 & 8 & 4 & 2 & 0 \\
\hline 14 & 31 & F & 537,496 & 20 & 24 & 7 & 7 & 8 & 8 & 4 & 2 & 0 \\
\hline 15 & 5 & $\mathrm{~F}$ & 537,499 & 8 & 4 & 6 & 6 & 6 & 6 & 4 & 2 & 0 \\
\hline 16 & $61 / 2$ & $\mathrm{~F}$ & 505,517 & 4 & 5 & 6 & 6 & 8 & 8 & 6 & 2 & 0 \\
\hline 17 & 16 & F & 452,321 & 12 & 10 & 7 & 7 & 8 & 6 & 4 & 2 & 0 \\
\hline 18 & 20 & M & 531,394 & 21 & 14 & 6 & 6 & 8 & 8 & 6 & 2 & 0 \\
\hline 19 & 33 & M & 375,110 & 66 & 12 & 7 & 7 & 8 & 8 & 4 & 2 & 0 \\
\hline 20 & 6 & $\mathrm{~F}$ & 550,230 & 4 & 5 & 6 & 5 & 6 & 8 & 6 & 2 & 2 \\
\hline 21 & 13 & M & 552,114 & 12 & 15 & 6 & 6 & 8 & 8 & 4 & 2 & 0 \\
\hline 22 & 5 & $\mathrm{~F}$ & 554,890 & 6 & 8 & 6 & 6 & 8 & 8 & 4 & 2 & 0 \\
\hline 23 & 26 & M & 540,882 & 20 & 12 & 7 & 7 & 8 & 8 & 6 & 2 & 0 \\
\hline 24 & 5 & F & 481,133 & 12 & 8 & 6 & 6 & 8 & 6 & 6 & 4 & 2 \\
\hline 25 & 5 & M & 566,346 & 4 & 6 & 6 & 6 & 8 & 6 & 4 & 2 & 0 \\
\hline
\end{tabular}

Table 9. Dissection tonsillectomy.

\begin{tabular}{ccccccccccccc}
\hline S No & Age & Sex & $\begin{array}{c}\text { Hospital } \\
\text { number }\end{array}$ & $\begin{array}{c}\text { Blood loss } \\
\text { (in ml) }\end{array}$ & $\begin{array}{c}\text { Operation } \\
\text { time } \\
\text { (in min) }\end{array}$ & $\begin{array}{c}\text { Normal diet } \\
\text { (in days) }\end{array}$ & $\begin{array}{c}\text { Normal } \\
\text { activity } \\
\text { (in days) }\end{array}$ & $\begin{array}{c}\text { Pain 6 } \\
\text { hour }\end{array}$ & $\begin{array}{c}\text { Pain } \\
\text { pod 1 }\end{array}$ & $\begin{array}{c}\text { Pain } \\
\text { pod 3 }\end{array}$ & $\begin{array}{c}\text { Pain } \\
\text { pod 5 }\end{array}$ & $\begin{array}{c}\text { Pain } \\
\text { pod 7 }\end{array}$ \\
\hline 1 & 12 & M & 491,684 & 60 & 20 & 5 & 7 & 8 & 8 & 4 & 2 & 0 \\
2 & 13 & M & 482,123 & 40 & 25 & 7 & 10 & 8 & 10 & 6 & 4 & 2 \\
3 & 7 & M & 560,225 & 60 & 25 & 6 & 6 & 10 & 8 & 8 & 6 & 4 \\
4 & 29 & F & 499,575 & 80 & 40 & 10 & 10 & 10 & 10 & 6 & 6 & 4 \\
5 & 29 & F & 505,172 & 40 & 20 & 10 & 10 & 10 & 8 & 6 & 6 & 4 \\
6 & 8 & F & 503,837 & 60 & 40 & 7 & 7 & 8 & 8 & 8 & 6 & 2 \\
\hline
\end{tabular}




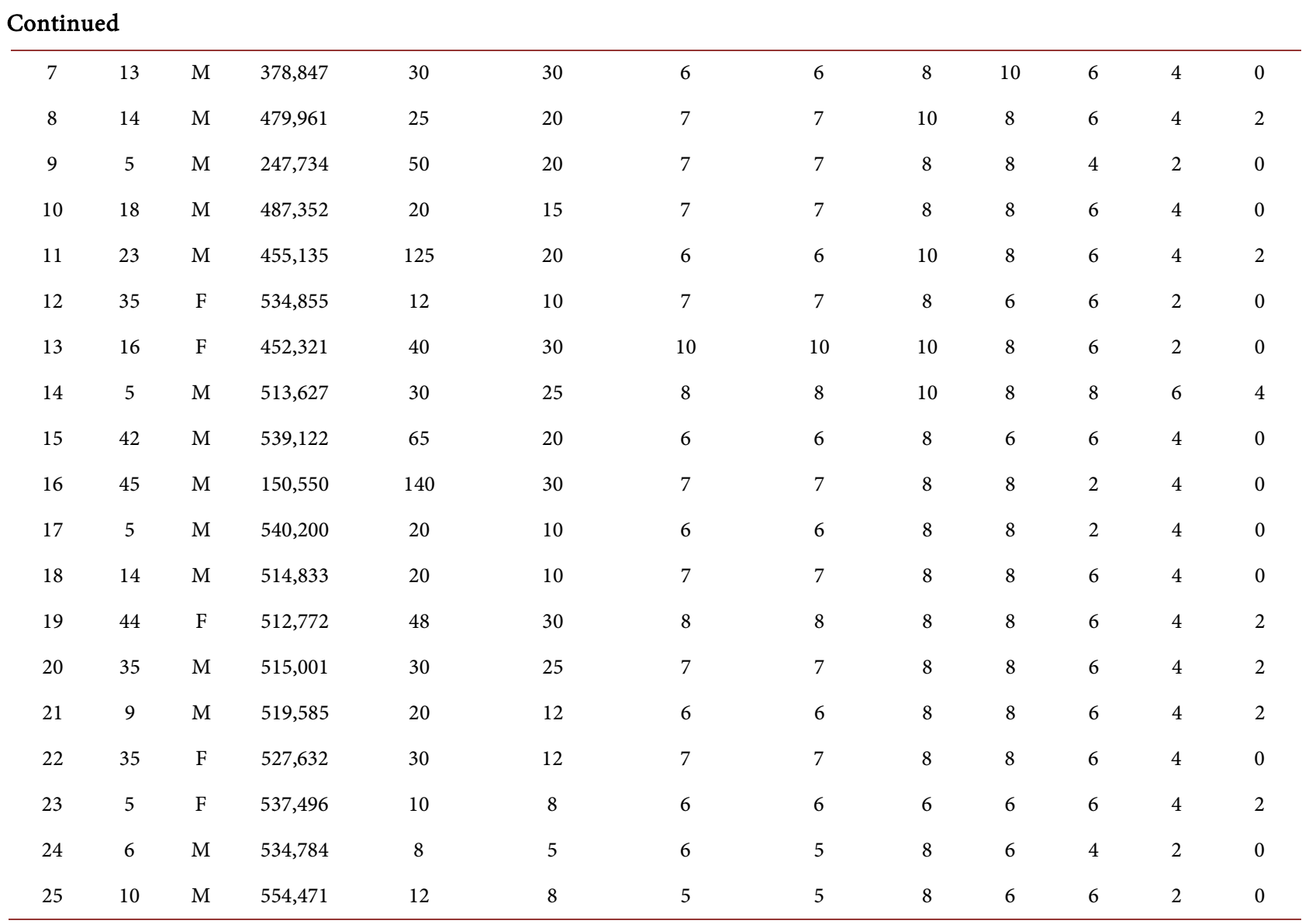

The surgical technique of coblation tonsillectomy is based on dissection of the tonsil in the relatively bloodless tonsillar muscular plane, using an Arthro Care Evac 70 Arthro Wand (Arthro Care Corp., Sunnyvale, CA). The operating principle of coblation and bipolar diathermy or electrosurgery is similar. In both, an alternative current passing between the active electrodes in the tip of the device produces destruction of the target tissue adjacent to the electrodes. In bipolar diathermy, direct contact between electrodes and tissue produces local temperatures of $400^{\circ} \mathrm{C}$ to $600^{\circ} \mathrm{C}$ resulting in heating of intracellular contents and subsequent vaporization of the cell. But coblation fills the physical space between the electrodes with a medium rich in sodium (e.g. isotonic saline). By coblation the medium is dissociated into free sodium ions, which will disrupt the intercellular bonds, resulting in tissue dissociation. This is achieved at temperatures between $60^{\circ} \mathrm{C}$ to $70^{\circ} \mathrm{C}$ with minimal collateral thermal tissue damage. And, the presence of cool, irrigating isotonic saline helps to limit the amount of heat delivered to the surrounding structures and a clear surgical field [15] [16].

In this study we compared two techniques of tonsillectomy, the coblation and traditional cold dissection in terms of intraoperative efficiency and post-operative morbidity. With these measures, this study could have an overview which method is better comparatively.

In our study, the patients' age ranged from 5 years to 45 years old with mean 
of 18.3 years old in coblation and mean of 19.1 in dissection type. There was no significant difference between the mean age of two groups ( $p>0.05)$, being 18.3 years in coblation and 19.1 years in traditional group which means that study groups are comparable. This study design is similar to that of Omrani et al. [17]. Paediatric age group (5 - 12 years old) were 11 for coblation and 10 for cold dissection type, adolescent (13 - 18 years old) were 3 for coblation and 6 for cold dissection type and adult (19 years old and above) were 11 for coblation and 10 for cold dissection type. Divided in age group, number of patients was almost equivalent in pediatric and adult group while adolescent accounted a smaller number of cases. Here the study showed that incidence of tonsillectomy may vary according to age group. A similar finding regarding age distribution was also noted in a study by Vestergard et al. [18].

The main objectives of this study were to evaluate the intraoperative efficiency and post-operative morbidity and the result showed that there was statistically significant difference in intraoperative time in coblation tonsillectomy comparing with cold dissection tonsillectomy (mean operative time is 13.4 for coblation and 20.4 for cold dissection with p value less than 0.05 ). In our study intraoperative blood loss was significantly less for coblation $(18.9 \mathrm{ml})$ compared to traditional $(43.0 \mathrm{ml})$ with $\mathrm{p}$ value 0.002

Coblation instrumentation uses a bipolar radio frequency waves that are transmitted by conductive solution (i.e. isotonic) between the device and the target tissue. Here same instrument is ablating the target tissue and also coagulating bleeding point during the procedure, thus reducing the time and blood loss compared to cold dissection where usually surgeon had to dissect the tonsils first before using any hemostasis techniques such as ligation or electrocautery diathermy.

In our study, average postoperative pain score 6 hours after operation was 7.6 for coblation and 8.5 for cold dissection with a significant $p$ value of 0.002 . In post-operative day 5, pain score average was 2.8 for coblation and 3.9 for cold dissection with a significant $\mathrm{p}$ value of 0.003 . Thus, there is significantly less pain in coblation six hours and 5 days after the operation. However, there were no differences of pain severity between the two methods at day 1, 3 and 7 postoperative. Generally, in comparing the overall post-operative pain score between coblation and cold dissection tonsillectomy, there was no significant difference between coblation and cold dissection side ( $\mathrm{p}$ value 0.1 ). This may be due to a small sample size. However, based on pain score on a daily basis there was statistical difference in post-operative pain score during 6 hours and 5 days post-operative. From the above result, it looks like patient did benefit in having less pain in coblation in immediate post-operative period and day 5 compared to cold dissection. In the following days post operatively (day 1, 3 and 7); there was slight difference in pain score which was not statistically significant, but in favor of coblation. This also showed that post-operative pain score in coblation tonsillectomy still superior and not inferior to cold dissection tonsillectomy. 
In our study, there is no post-operative hemorrhage in both groups, which confirmed that there was no relative increase in postoperative hemorrhage in coblation compared to traditional method which is similar to the studies conducted by Divi et al. and Glade et al. [19] [20].

In our study, average time taken to return to normal diet among coblation was 6.4 days and dissection was 7.0 days with $p$ value of 0.078 which was not statistically significant. However, time to return to normal activity, average time taken to return to normal activity among coblation was 6.3 days and dissection was 7.1 days with a significant $\mathrm{p}$ value of 0.024 .

Compared to cold dissection, the most significant disadvantages of coblation were a learning curve, although it was relatively short, and the expense of the wand. Costs of coblation tonsillectomy include a wand for each patient or maximum up to 2 - 3 patients; further use will affect the favorable intra and post-operative outcome of surgery. In addition, this tool is substantially costlier than that used to perform cold dissection.

\section{Funding}

None.

\section{Conflicts of Interest}

None declared.

\section{Ethical Approval}

Not required.

\section{Limitation of the Study}

The sample size is small. A larger sample size and randomization would have improved the value of our study a little bit more.

\section{References}

[1] Pinder, D.K., Wilson, H. and Hilton, M.P. (2001) Dissection versus Diathermy for Tonsillectomy. Cochrane Database of Systematic Reviews, CD002211.

[2] Baily, B.J. (1997) Tonsils and Adenoids: Snapshots from the Laryngoscope Scrapbook. Laryngoscope, 107, 301-306. https://doi.org/10.1097/00005537-199703000-00003

[3] McGuire, N.G. (1967) A Method of Guillotine Tonsillectomy with an Historical Review. The Journal of Laryngology \& Otology, 81, 187-195. https://doi.org/10.1017/S0022215100066949

[4] Goycoolea, M.V., Cubillos, P.M. and Martinez, G.C. (1982) Tonsillectomy with a Suction Coagulator. Laryngoscope, 92, 818-819. https://doi.org/10.1288/00005537-198207000-00021

[5] Weingarten, C. (1997) Ultrasonic Tonsillectomy: Rationale and Technique. Otolaryngology_Head and Neck Surgery, 116, 193-196. https://doi.org/10.1016/S0194-5998(97)70324-3 
[6] Martinez, S.A. and Akin, D.P. (1987) Laser Tonsillectomy and Adenoidectomy. Otolaryngologic Clinics of North America, 20, 371-376.

[7] Mann, D.G., St. George, C., Scheiner, E., et al. (1984) Tonsillectomy-Some like It Hot. Laryngoscope, 94, 677-679. https://doi.org/10.1288/00005537-198405000-00019

[8] Pang, Y.T., EL-Hakim, H. and Rothera, M.P. (1994) Bipolar Diathermy Tonsillectomy. Clinical Otolaryngology and Allied Sciences, 19, 355-357. https://doi.org/10.1111/j.1365-2273.1994.tb01247.x

[9] Saleh, H.A., Cain, A.J. and Mountain, R.E. (1999) Bipolar Scissor Tonsillectomy. Clinical Otolaryngology and Allied Sciences, 24, 9-12. https://doi.org/10.1046/j.1365-2273.1999.00200.x

[10] Andrea, M. (1993) Microsurgical Bipolar Cautery Tonsillectomy. Laryngoscope, 103, 1177-1178. https://doi.org/10.1288/00005537-199310000-00018

[11] ArthroCare Corporation (2000) Coblator Plasma Surgery System. ENTec, Sunnyvale, $\mathrm{CA}$.

[12] Woloszko, J. and Gilbride, C. (2001) Coblation Technology: Plasma Meditation Ablation for Otolaryngology Applications. Arthro Care Corporation, Sunnyvale, 102-114.

[13] Myatt, H.M. and Myatt, R.A. (1998) The Development of a Pediatric Quality of Life Questionnaire to Measure Post-operative Pain Following Tonsillectomy. International Journal of Pediatric Otorhinolaryngology, 44, 115-123. https://doi.org/10.1016/S0165-5876(98)00053-6

[14] Pizzuto, M.P., Brodsky, L., Duffy, L., Gendler, J. and Nauenberg, E. (2000) A Comparison of Microbipolar Cautery Dissection to Hot Knife and Cold Knife Cautery Tonsillectomy. International Journal of Pediatric Otorhinolaryngology, 52, 239-246. https://doi.org/10.1016/S0165-5876(00)00293-7

[15] Chinjpairooj, S., Feldman, M.D., Saunders, J.C. and Rhaler, E.R. (2001) A Comparison of Monopolar Electrosurgery to a New Multipolar Electrosurgical System in a Eat Model. Laryngoscope, 111, 213-217. https://doi.org/10.1097/00005537-200102000-00005

[16] Plant, T.L. (2002) Radiofrequency Treatment of Tonsillar Hypertrophy. Laryngoscope, 112, 20-22. https://doi.org/10.1002/lary.5541121408

[17] Omrani, M., Barati, B., Omidifar, N., Okhovvat, A.R. and Hashemi, S.A.G. (2012) Coblation versus Traditional Tonsillectomy: A Double Blind Randomized Controlled Trial. Journal of Research in Medical Sciences. The Official Journal of Isfahan University of Medical Sciences, 17, 45-50.

[18] Vestergaard, H., Wohlfahrt, J., Westergaard, T., Pipper, C., Rasmussen, N. and Melbye, M. (2007) Incidence of Tonsillectomy in Denmark, 1980 to 2001. The Pediatric Infectious Disease Journal, 26, 1117-1121. https://doi.org/10.1097/INF.0b013e31814536ba

[19] Divi, V. and Benninger, M. (2005) Postoperative Tonsillectomy Bleed: Coblation versus Noncoblation. Laryngoscope, 115, 31-33. https://doi.org/10.1097/01.mlg.0000150682.62517.0e

[20] Glade, R.S., Pearson, S.E., Zalzal, G.H. and Choi, S.S. (2006) Coblation Adenotonsillectomy: An Improvement over Electrocautery Technique? Otolaryngology-Head and Neck Surgery, 134, 852-855.

https://doi.org/10.1016/j.otohns.2005.11.005 